Ann. Biol. anim. Bioch. Biophys., I976, 16 (3), 363-372.

\title{
ESTROGEN-GONADOTROPIN INTERACTION IN POSTNATAL FEMALE RATS, AND THE INDUCTION OF ANOVULATORY STERILITY BY TREATMENT WITH AN ESTROGEN-ANTAGONIST
}

\author{
K.-D. DÖHLER, A. VON ZUR MÜHLEN and Ursula DÖHLER \\ Dept. Klinische Endokrinologie, \\ Medizinische Hochschule Hannover, \\ 3000 Hannover, Karl-Wiechert-Allee 9 (Germany)
}

\begin{abstract}
SUMMARY
Ten days old female Sprague-Dawley rats were treated with bilateral adrenalectomy (ADX), ovariectomy (OVX), adrenalectomy combined with ovariectomy (ADX + OVX), or with the estrogen antagonist I.C.I. 46,474. Blocd samples were taken 5 days later and serum LH and FSH were measured by radioimmunoassay. ADX, OVX and ADX + OVX resulted in a rise of serum LH and FSH, but treatment with I.C.I. 46,474 lowered serum levels of LH and FSH. Another group of female rats was treated with I.C.I. 46,474 from day 5 to 15 of life and received a single injection of $\mathrm{I} .25 \mathrm{mg}$ testosterone propionate (TP) on day I4. All rats showed anovulatory sterility when adult, in contrast to control animals which had received the TP injection on day I 4 , but no treatment with the estrogen antagonist. Treatment with I.C.I. 46,474 alone from birth to day 28 of age also resulted in anovulatory sterility and reduced the ovarian weight significantly.

The results indicate, that estrogens are involved in the postnatal development and priming of the stimulatory feedback of estrogens on pituitary gonadotropin release (" surge system ")which is necessary for the normal induction of ovulation in rats. They further show the stimulatory action of serum estradiol on gonadotropic hormone release already in very young immature female rats as well as an inhibitory action of the ovaries and the adrenals.
\end{abstract}

\section{IN'TRODUC'TION}

Treatment of newborn female rats with androgens has a masculinizing effect on the differentiation of the hypothalamus, which results in the development of the male pattern of gonadotropin secretion (BARRACLOUGH, I96I). Following such treatment animals neither show estrous cycles nor ovulations when adult. The critical period during which masculinization is possible extends up to day to of life 
(BARRACLOUGH, I96I). The end of this critical period coincides with the beginning of a new period, which in normal female rats is characterized by high levels of circulating estradiol and FSH (MEIJs-Rozlors et al., I973 ; DöHL.ER and WUTTTKE, 1974 and 1975) and by sporadic LH peaks in the serum (DöHLER and WUTTKE, I974, 1975). Male rats also have high serum estradiol levels during this age, but low LH and FSH concentrations (DÖHLER and WUTTKE, I974, I975). DÖHLER (1974) suggested, that the high circulating estradiol levels during approximately days 9 to I9 of age may imprint the female hypothalamus for estrogen sensitivity and thus enable it to respond to further estrogen stimulation with gonadotropin release. It is known, that estradiol has a stimulatory influence on gonadotropin release in adult female animals (Hotchkiss et al., I971 ; MiYake, I969; NeILL et al., I97I) and also shortly before puberty (RAMIREz and SAwYER, I965; YING and GREEP, 197I). In the male rat postnatally circulating androgens (RESKo et al., I968; DöHLER and WUTTKE, I975) may prevent the estrogen sensitization of the hypothalamus. The present study was. designed to clarify the estrogen-gonadotropin interaction in postnatal rats by studying the effects of estrogen suppression on sexual development.

\section{MATERIALS AND METHODS}

The Spague-Dawley rats used in these experiments were raised in our light controlled (light period from $05.00 \mathrm{~h}$ to $\mathrm{Ig} .0 \mathrm{o} \mathrm{h})$ and air-conditioned $\left(22 \pm \mathrm{I}^{\circ} \mathrm{C}\right)$ animal rooms. Three separate experiments were carried out.

\section{Experiment 1}

A total of I $_{5} \mathrm{I}$ female rats, Io days of age, were allotted to 6 treatment groups, which were submitted to the following treatments: $\mathrm{r}$. bilateral ovariectomy (OVX), 2. bilateral adrenalectomy $(\mathrm{ADX})$, 3. bilateral ovariectomy combined with bilateral adrenalectomy (OVX + ADX), 4. sham ovariectomy and sham adrenalectomy, 5. daily subcutaneous injections from day ro to day $I_{5}$ of age, of $0.05 \mathrm{mg}(2 \mathrm{mg} / \mathrm{kg}$ body weight) of the estrogen antagonist I.C.I. 46,474 , the trans-isomer of $I-(p-\beta$-dimethylaminoethoxyphenyl)- 1,2 -diphenylbut- 1 -ene (HARPER and WalPOLE, 1967; WALPOLE, I968) in $0.05 \mathrm{ml}$ castor oil, 6. subcutaneous injections of the vehicle (castor oil) from day to to day 15 of age. All animals were decapitated at 15 days of age. Their blood was collected individually and their serum was assayed for LH and for FSH. The radioimmunoassay kits and procedures were the same as described by MONROE et al. (I969) and by DAAse and PArLow (1971).

\section{Experiment 2}

Io newborn female rats were treated with a daily subcutaneous injection of $0.05 \mathrm{mg}$ I.C.I. 46,474 from day 5 of age up to day I5. They additionally received a single subcutaneous injection of $1.25 \mathrm{mg}$ testosterone propionate (TP) on day 14 . Ten control females received oil injections from day 5 to 15 and a single subcutaneous injection of $1.25 \mathrm{mg}$ TP on day 14 of age. After vaginal opening all females were paired with experienced males and their vaginal smears were recorded daily. Three experimental and 3 control animals were sacrificed with 38 days of age and their ovarian and adrenal weights were recorded.

\section{Experiment 3}

I 2 female rats were treated with a daily dose of $0.05 \mathrm{mg}$ I.C.I. 46,474 in $0.05 \mathrm{ml}$ castor oil from the day of birth up to day 28 of age. On day 38 of age 3 rats were sacrificed and their gona- 
dal and adrenal weights were recorded. Another 3 females were sacrificed on day 60 of age. Again gonadal and adrenal weights were recorded. The rest of the femals were placed with sexually experienced males and their vaginal smears were checked regularly.

\section{RESUL,TS}

\section{Experiment 1}

The serum LH and FSH levels of OVX, ADX, OVX + ADX, anti-estrogen treated and of the control animals are shown in table $\mathrm{I}$. The control animals treated with sham surgery and the control animals treated with subcutaneous oil injections had similar serum $\mathrm{L}_{\mathrm{H}}$ and FSH levels. Their results were combined, therefore, for statistical purposes.

TABLE I

Effects of ovariectomy (OVX), advenalectomy (ADX), ovariectomy combined with adrenalectomy (OVX+ADX) and anti-estrogen (I.C.I. 46,474) treatment on serum $L H$ and FSH in postnatal female rats

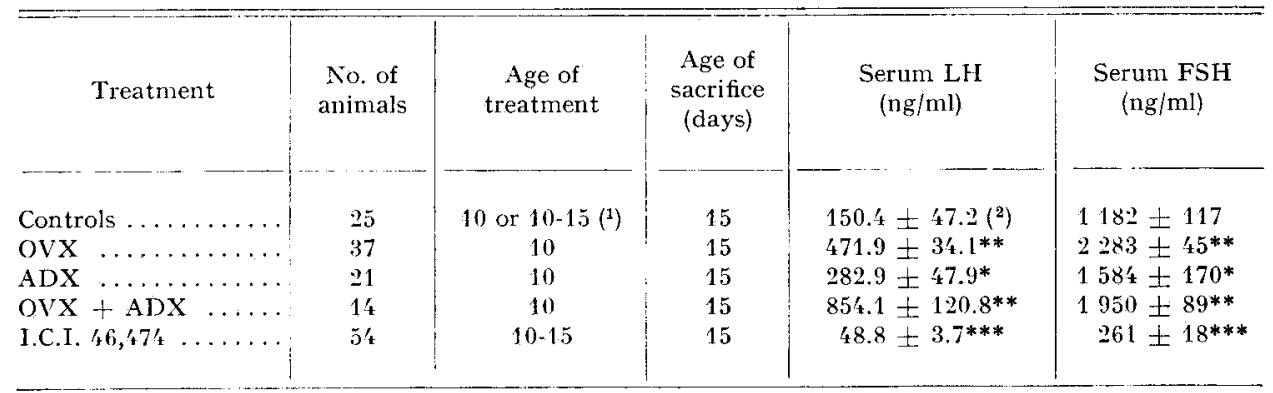

(1) One control group received sham OVX and sham ADX at 10 days of age, another control group received oil injections from day 10 to 15 of age. As the results of both groups were not significantly different, they were combined.

(2) Mean \pm SEM.

* Significantly higher than control group $(p<0.05)$.

** Significantly higher than control group $(p<0.005)$.

*** Significantly lower than control group $(p<0.005)$.

Control animals displayed the same characteristic $\mathrm{LH}$ pattern, shown previously for untreated female rats of this age (DöHLER and WUTTKE, I974, I975; DöHI,ER, I975). Low serum LH levels (below $50 \mathrm{ng} / \mathrm{ml}$ were found in $40 \mathrm{p}$. Ioo of the rats, moderately high levels (90 to $300 \mathrm{ng} / \mathrm{ml}$ ) were measured in $35 \mathrm{p}$. Ioo of the animals and very high levels (above $300 \mathrm{ng} / \mathrm{ml}$ ) were found in the remaining animals. OVX, $\mathrm{ADX}$ and $\mathrm{OVX}+\mathrm{ADX}$ resulted in an increase in serum LH concentration (fig. I). Only very high or moderately elevated serum $\mathrm{L}_{4} \mathrm{H}$ levels were found in these animals. Treatment with the anti-estrogen I.C.I. 46,474 abolished the very high and most 


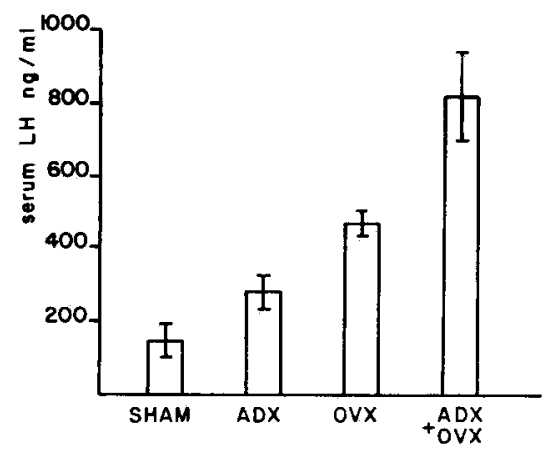

FIG. I. - Serum LH levels in postnatal female rats after bilateral adrenalectomy (ADX), ovariectomy (OVX) adrenalectomy combined with ovariectomy (ADX + OVX) or sham-operation (SHAM). Operations were performed on day ro after birth, blood samples were collected 5 days later. The bars represent the means. Standard error of the mean is indicated on top of each bar.

of the moderately elevated $\mathrm{LH}$ levels, which were present in control animals. Only low and a few moderately elevated $\mathrm{L} / \mathrm{H}$ levels were measured after anti-estrogen treatment (fig. 2).

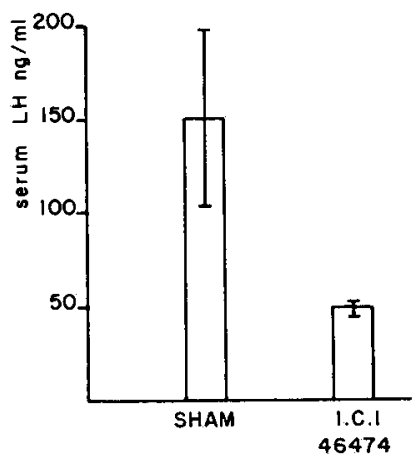

FIG. 2. - Serum LH levels in postnatal female rats treated with the estrogen antagonist I.C.I. 46,474 from day 10 to 15 of life. Blood samples were taken on day 5 . SHAM = control animals, which received the vehicle only.

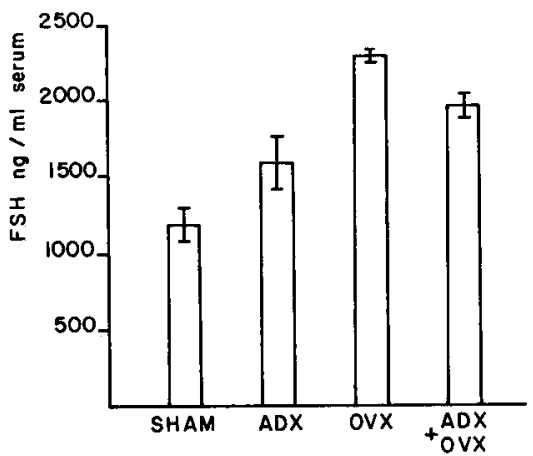

FIG. 3. - Serum FSH levels in postnatal female rats after bilateral adrenalectomy (ADX), ovariectomy (OVX), adrenalectomy combined with ovariectomy (ADX + OVX). Further explanations, see text of figure $\mathrm{I}$. 
The already high serum FSH levels in control animals of this age were increased after ADX, OVX and after ADX + OVX (fig. 3). Low FSH levels were measured after I.C.I. 46,474 treatment (fig. 4).

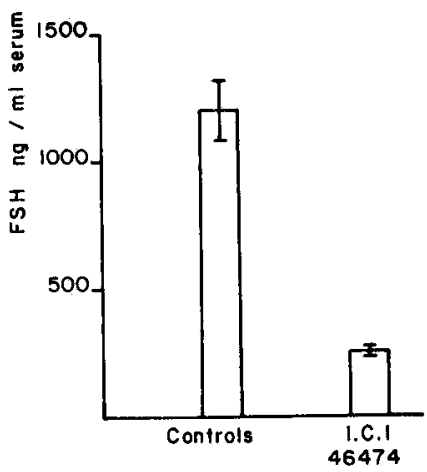

FIG. 4. - Serum FSH levels in postnatal female rats treated with the estrogen antagonist I.C.I. 46,474 from day 10 to 15 of life. Blood samples toeve taken on day I $_{5}$. Control animals received the same treatment with the vehicle only.

\section{Experiment 2}

Female rats which were treated with I.C.I. 46,474 from day 5 to 5 of age and which had received a single injection of $1.25 \mathrm{mg}$ TP on day 14 showed premature vaginal opening ( $\mathrm{I} 9.2 \pm 0.2$ days), which was followed by predominantly nucleated and/or cornified vaginal cytology. From day $6_{5}$ of age on these animals

TABLE 2

Effects of postnatal anti-estrogen (I.C.I. 46,474)

and TP treatment on vaginal opening, ovarian and adrenal weights, estrons cycles and mating in female rats

\begin{tabular}{|c|c|c|c|c|c|c|c|}
\hline Treatment & $\begin{array}{l}\text { Age of } \\
\text { treatment } \\
\text { (days) }\end{array}$ & $\begin{array}{l}\text { Day of } \\
\text { vaginal } \\
\text { opening }\end{array}$ & $\begin{array}{l}\text { Cycles } \\
\text { (adult) }\end{array}$ & $\begin{array}{l}\text { Mating } \\
\text { (adult) }\end{array}$ & $\begin{array}{l}\text { Age at } \\
\text { autopsy } \\
\text { (days) }\end{array}$ & $\begin{array}{l}\text { Ovarian } \\
\text { wt (mg) }\end{array}$ & $\begin{array}{l}\text { Adrenal } \\
\text { wt (mg) }\end{array}$ \\
\hline I.C.I. $46,474 \ldots$ & $1-28$ & $\begin{array}{l}\text { before } \\
\text { day } 30\end{array}$ & no & no & 38 & $1.3 \pm 0.2(1)$ & $10.6 \pm 0.6$ \\
\hline I.C.I. $46,474 \ldots$ & $1-28$ & $\begin{array}{l}\text { before } \\
\text { day } 30\end{array}$ & no & no & 60 & $3.5 \pm 0.2$ & $24.7 \pm 0.5$ \\
\hline Controls ...... & - & $38.8 \pm 0.6$ & regular & yes & 38 & $13.1 \pm 0.9$ & $12.2 \pm 0.9$ \\
\hline $\begin{array}{r}\text { I.C.I. } 46,474 \ldots \\
\quad+\mathrm{TP} \ldots\end{array}$ & $\begin{array}{c}5-15 \\
14\end{array}$ & $19.2 \pm 0.2$ & no & no & 38 & $5.4 \pm 0.4$ & $15.4 \pm 0.8$ \\
\hline Oil $\begin{aligned} & \ldots \ldots \ldots \\
& +\mathrm{TP} \ldots\end{aligned}$ & $\begin{array}{c}5-15 \\
14\end{array}$ & $24.4 \pm 0.2$ & regular & yes & 38 & $13.2 \pm 1.0$ & $12.4 \pm 0.9$ \\
\hline
\end{tabular}

(1) Mean \pm SEM. 
retained constant vaginal cornification. They never ovulated or mated when paired with sexually experienced males. Their ovaries were very small $(5.4 \pm 0.4 \mathrm{mg})$ at 38 days of age (table 2 ).

The control rats, which were treated with castor oil from day 5 to $\mathrm{I}_{5}$ and had received a single injection of $\mathrm{I} .25 \mathrm{mg}$ TP on day $\mathrm{I}_{4}$ also displayed premature vaginal opening (24.4 \pm 0.2 days), which was not directly followed by cyclic vaginal cytology or ovulation. The first functional estrus and ovulation occurred, however, at the normal time ( $40.6 \pm 0.9$ days). When caged with sexually experienced males they showed normal mating and subsequent pregnancies.

\section{Experiment 3}

All female rats treated from birth to day 28 with I.C.I. 46,474 displayed premature vaginal opening before day 30 of age. While vaginal opening in untreated control rats $(38.8 \pm 0.6$ days) was always followed by more or less regular vaginal cycles, the anti-estrogen treated females did not show vaginal cycles or ovulation. The majority of cells in their vaginal smears were nucleated and sometimes cornified. These animals never mated with experienced males. Ovaries taken on 38 or 60 days of age were very small (table 2) and resembled in size the ovaries of I5 $_{5}$ or 2I days old control animals. No differences were found in adrenal weights.

\section{DISCUSSION AND CONCLUSIONS}

High serum estradiol levels have been measured in male (DÖHLER and WUTTKE, I975) and female rats (Weisz and Gunsalus, I973; Merus-Roelofs et al., I973; ChFng and Johnson, I973-I974; DöHLER and WuTTKE, I975) between approximately day Io and 20 of age. This rise in serum estradiol is accompanied by high serum FSH levels and by sporadic $\mathrm{LH}$ peaks in the female rats, but not in the males (DÖHLER and WUTTKE, I974, I975).

Blockade of estradiol action on target tissues was carried out by means of the potent estrogen antagonist I.C.I. 46,474, which has minimal estrogenic activity (HARPER and WALPOLE, I967). Treatment with this drug for 5 days eliminated serum $\mathrm{LH}_{\mathrm{H}}$ peaks and reduced serum $\mathrm{FSH}$ to very low levels in female rats on day $\mathrm{I}_{5}$ of age. Treatment with clomiphene, another anti-estrogen, had the same effect (DÖHLER, unpublished). These results indicate, that estradiol can have a positive action on $\mathrm{LH}$ and FSH release already in postnatal female rats, and that the high FSH levels and the sporadic I,H peaks found in female rats between day Io and 20 of age (DÖHLER and WUTTKE, I974, I975), are most likely to be due to the stimulatory action of the high levels of circulating estradiol found during the same period. It is highly unlikely that I.C.I. 46,474 directly inhibited gonadotropin release at the pituitary or hypothalamic level because of the following reasons:

I. I.C.I. 46,474 did not inhibit gonadotropin release in adult ovariectomized rats (DÖHLER unpublished) as well as in prepubertal male rats as judged from the weight change of ventral prostate and seminal vesicles at doses which were higher 
than the doses applied here $(5 \mathrm{mg} / \mathrm{kg} /$ day compared to $2 \mathrm{mg} / \mathrm{kg} /$ day $)$. Much higher doses were necessary to cause significant reduction of seminal vesicle weight $(25 \mathrm{mg} / \mathrm{kg} / \mathrm{day}$ ) and ventral prostate weight (I00 $\mathrm{mg} / \mathrm{kg} /$ day), but these reductions were still less than those obtained with conventional estrogens (HARPER and WALPOLE, I967).

2. Orulation was restored in adult I.C.I. 46,474 treated female rats by the application of either LH, LRH or estrogen alone (LABHSETWAR, 1970). Ovulation was also restored after I.C.I. 46,474 treatment, when a copulatory stimulus was given, which is known to act directly on the hypothalamus via the central nervous system, bypassing the positive estrogen feedback (LABHSETWAR, I970).

3. In reflex ovulating species such as the rabbit, where positive feedback action of estrogen is unlikely to play a role, I.C.I. 46,474 does not inhibit ovulation (HARPER and WALPOLE, I967).

4. Unlike neural blocking agents (EVERETT, I96I) I.C.I. 46,474 did not block ovulation when given on the day of proestrus before the critical period of neural activation for gonadotropin release (LABHSETWAR, I970). As far as the effect of estrogen antagonism on the release of $L_{4} \mathrm{H}$ is concerned, these results are in agreement with the results of WUTTKE et al. (I975) and WUTTKE and GeLATo (this volume), who found that treatment of postnatal rats with estrogen antiserum caused a decrease in serum LH. However, treatment with estrogen antiserum resulted in increased serum FSH levels. The combined results from the two laboratories seem to indicate, that the levels of serum estrogen concentration may have to be different for LH and FSH in order to exert their stimulatory or inhibitory action on the release of the two gonadotropins (see also WUTTKE and GELATO, this volume).

The source of estradiol in postnatal female rats is not definitely certain. MEIJSROELOFS et al. (1973) found the ovaries to be the source of prepubertal estradiol secretion, WEIsz and GUNSAL,US (1973), however, reported, that most of the circulating estradiol derives from the adrenals. Keeping in mind, that estradiol also shows a depressing action on the release of gonadotropins in ovariectomized prepubertal and adult rats (OJEDA and RAMIREZ, I973-74; RAMIREZ and MCCANN, I963), our results of elevated gonadotropin levels after adrenalectomy, ovariectomy and adrenalectomy combined with ovariectomy could present indirect evidence, that estradiol is being secreted by both, the ovaries and the adrenals in prepubertal female rats. However, it seems more likely, that other steroids from adrenal and ovarian origin are responsible for the inhibitory action of the two organs on gonadotropic hormone release, as serum gonadotropins were low, when estrogen action selectively was blocked in our otherwise intact animals.

PFEIFFER (I936) has shown, that the process of feminization is apparently not dependent on the presence of female sex hormones. Postnatal gonadectomy resulted in the development of the ability to display regular estrous cycles in adult male and female rats with implanted ovaries. Implantation of testes (PFFIFFER, I936) or application of androgens (BARRACLOUGH, I96I ; GORSKI and BARRACLOUGH, I963), to postnatal female rats resulted in the loss of this ability. Masculinization of the hypothalamus in rats is only possible up to day ro of age (BARRACLOUGH, I96r). Incidently, when estradiol levels start to rise at the end of this period, masculinization is not possible any more. Female rats treated with I.25 mg TP on day I4 of age - a dose which resulted in anovulatory sterility when given at day 5 of 
age - , displayed regular estrous cycles, ovulation, mating behaviour and pregnancies. These results are in agreement with those of BARRACLOUGH (I96r).

However, when the action of endogenous estrogens was antagonized by I.C.I. 46,474 from day 5 to I5 after birth in female rats and the animals were treated with a single injection of $\mathrm{I} .25 \mathrm{mg}$ TP on day I4, no estrous cycles or ovulation were detected when these animals were adult. If this was due to the TP injection at a time, when endogenous estrogens had not developed their priming action on the hypothalamus yet, or if it was due to the estrogen antagonist alone, cannot be clarified at this time. Treatment of female rats with the estrogen antagonist alone from birth to day 28 of age also resulted in the loss of cyclicity and ovulation when adult. These results seem to indicate, that female sex hormones, i.e. estradiol, do play a significant role postnatally in the development of cyclicity.

KATO et al. (197I) have shown, that the ability of the hypothalamus and the median eminence to take up and to retain estradiol is still low in postnatal female rats at I2 days of age. At 25 days, however, this ability has developed to almost adult levels. The results of our study seem to indicate, that the rising levels of serum estradiol around day ro of life are involved in the formation of estrogen receptors in the brain of female rats, which from then on can modulate the feedback action of estrogens on gonadotropin release. It is possible, that the inhibition of estrogen action in the postnatal rat by I.C.I. 46,474 prevented the formation of estrogen receptors in the brain, and thus prevented the development of the stimulatory estrogen feedback on gonadotropin release (" surge system " or " cyclic center "), causing anovulatory sterility. Estradiol application at 65 and 68 days of age did not induce ovulation in these rats (DöHLER, unpublished).

Androgen levels have been shown to be high in male rats after birth (RESKo et al., I968; DöHLER and WUTTKE, I975), but low in females (DöHLER and WUTTKE, 1975). These androgens, secreted in males before the time serum estradiol begins to rise, may interfere with estrogen receptor formation in the hypothalamus, thus preventing the stimulatory feedback mechanism of estrogens to develop in the male rat. As perinatally gonadectomized male or female rats did not loose the ability to display estrous cyclicity with implanted ovaries as adults (PFEIFFER, I936), these animals probably have not been deprived of postnatal estrogens completely. Estrogens from the adrenals (WEIsz and Gunsalus, I973), or steroids which were metabolized to estrogens in peripheral organs like the liver and the lungs may have been sufficient for priming the " surge system ".

Sexual Maturation 3rd Workshop, August 31, September 3, 1975.

\section{ACKNOWLEDGEMENTS}

This work was supported by a grant of the Dautshe Forschungsgemsinschaft.

We wish to thank the NIAMDD-Rat Pituitary Hormone Distribution Program for the generous supply of rat LH and FSH radioimmunoassay kits. We also thank Dr. WALPOLE (Imperial Chemical Industries, Ltd., Macclesfield, England), who provided I.C.I. 46,474 and Dr. Richardson (The Merrel Company, Cincinatti, Ohio, U.S.A.) for the supply of clomiphene. 


\section{RÉSUMÉ}

\section{INTERACTION ESTROGÈNE-GONADOTROPINES CHEZ IA RATTE APRÈS LA NAISSANCE ET INDUCTION D'UNE STÉRILITÉ ANOVUL,ATOIRE PAR TRAITEMENT AVEC UN ANTIESTROGÈNE}

Des Rattes Sprague-Dawley de ro jours sont surrénalectomisées (ADX), ovairectomisées (OVX), surrénalectomisées et ovairectomisées (ADX + OVX) ou reçoivent un anti-estrogène (I.C.I. 46,474 ) .5 jours plus tard, on prélève du sang pour doser LH et FSH dans le sérum par une méthode radioimmunologique.

ADX, OVX, ADX + OVX provoquent une augmentation de LH et FSH, mais le traitement avec l'anti-estrogène abaisse le taux de LH et FSH dans le sérum.

Un autre groupe de Rattes est traité avec I.C.I. $4^{6,474}$ du $5^{\mathrm{e}}$ au $\mathrm{I} 5^{\mathrm{e}}$ jour après la naissance et reçoit une injection de propionate de testostérone (TP) le $\mathbf{I} 4^{\mathrm{e}}$ jour. A l'âge adulte toutes les femelles montrent une stérilité anovulatoire alors que les témoins qui ont reçu seulement l'injection de TP le $\mathrm{I}_{4} \mathrm{e}$ jour ovulent normalement.

Un traitement avec I.C.I. 46,474 de la naissance à l'âge de 28 jours induit également une stérilité anovulatoire et réduit significativement le poids des ovaires.

Ces résultats indiquent que les estrogènes sont indispensables pour le développement postnatal et l'induction de la rétroaction positive des estrogènes sur la secrétion des gonadotropines hypophysaires, nécessaire à l'induction de l'ovulation chez la Ratte. Ils montrent en outre l'action stimulante de l'estradiol sur la libération des hormones gonadotropes chez la Ratte immature, ainsi que l'action inhibitrice des ovaires et des surrénales.

\section{REFERENCES}

Barraclough C. A., I96I. Production of anovulatory, sterile rats by single injections of testosterone propionate. Endocrinology, 68, 62-67.

Cheng H. C., Johnson D. C., I973-I974. Serum estrogens and gonadotrophins in developing androgenized and normal female rats. Neuroendocrinology, 13, 357-365.

DaAne T. A., Parlow A. F., r97r. Periovulatory patterns of rat serum follicle stimulating and luteinizing hormone during the normal estrous cycle : effects of pentobarbital. Endocrinology, 88, $653-663$.

DÖHLER K.-D., 1974. Die hormonelle Steuerung der sexuellen Reifung, des weiblichen östruszyklus und der Gravidität bei der Ratte. Ph. D. thesis, University of Göttingen.

Döhler K.-D., 1975. Diurnal variations of hormone levels in prepuberal rats. Acta endocr. (Kbh.), Suppl. 193, 78 (abstract).

Döhler K.-D., Wutrke W., 1974. Serum LH, FSH, prolactin and progesterone from birth to puberty in female and male rats. Endocrinology, 94, 1003-1008.

DöHLER K.-D., WUTTKE W., I975. Changes with age in levels of serum gonadotropins, prolactin and gonadal steroids in prepubertal male and female rats. Endocrinology, 97, 898-907.

Everett J. W., I96r. The mammalian female reproductive cycle and its controlling mechanisms, 497-555, in : Young W. C., Sex and internal secretions, 3 rd ed., vol. I, Williams and Wilkins, Baltimore.

Gorski R. A., Barraclough C. A., I963. Effect of low dosages of androgen on the differentiation of hypothalamic regulatory control of ovulation in the rat. Endocrinology, 73, 210-216.

Hotchkiss J., Atrinson L. E., Knobil E., I97I. Time course of serum estrogen and luteinizing hormone $(\mathrm{L} H)$ concentrations during the menstrual cycle of the rhesus monkey. Endocrinology, 89, I77-183.

Harper M. J. K., Walpole A. L., 1967. A new derivative of triphenyl-ethylene : effect on implantation and mode of action in rats. J. Reprod. Fert., 13, IOI-II9.

Kato J., Sugimara N., Kobayashi T., I97I. Changing pattern of the uptake of estradiol by the anterior hypothalamus, the median eminence, and the hypophysis in the developing female rat, 698703, in : Hamburgh M., Barrington E. J. W., Hormones in development, proc., Appleton-CenturyCrofts, New York. 
LabHSEtwar A. P., I 97o. Role of estrogens in ovulation : a study using the estrogen-antagonist, I.C.I. 46, 474, Endocrinology, 87, 542-55I.

Meijs-Roelofs H. M. A., Uilenbroek J. Th. J., de Jong F. H., Weischen R., 1973. Plasma oestradiol-r> $\beta$ and its relationship to serum follicle stimulating hormone in immature female rats J. Endocr., 59, 295-304.

Miyake T., I969. Causal relationship between steroid secretion and pituitary luteinizing hormone release in the estrous cycle. Endocr. Jap., Suppl. I, 83.

Monroe S. E., Rebar. R. W., Gay V. L., Mupgley A. R. Jr, I969. Radioimmunoassay for determination of luteinizing hormone during the estrous cycle of the rat. Endocrinology, 85, 720-724.

Neill J. D., Freeman M. E., Tillson S. A., I97x. Control of the proestrous surge of prolactin and luteinizing hormone secretion by estrogens in the rat. Endocrinology, 89, 1448-I453.

OJEDA S. R., RAMiRez V. D., I973-I974. Short term steroid treatment on plasma LH and FSH in castrated rats from birth to puberty. Neuroendocrinology, 13, roo-I I4.

Pfeiffer C. A., 1936. Sexual differences of the hypophyses and their determination by the gonads. Am. J. Anat., 58, r95-226.

Ramirez V. D., McCann S. M., I963. Comparison of the regulation of luteinizing hormone (LH) secretion in immature and adult rats. Endocrinology, 72, 452-464.

Ramirez V. D., SAwYer C. H, I965. Advancement of puberty in the female rat by estrogen. Endocrinology, \%6, I $158-1 \mathrm{I} 68$.

Resko J. A., Feder A. A., Goy R. W., I968. Androgen concentrations in plasma and testes of developing rats. J. Endocr., 40, 485-49I.

Walpole A. L., I968. Non-steroidal drugs in relation to ovulation and implantation. J. Reprod. Fert., Suppl. 4, 3-14.

Wersz J., Gunsalus P., 1973. Estrogen levels in immature female rats : true or spurious-ovarian or adrenal?. Endocrinology, 93, 1057-1065.

Wuttke W., Döhler K.-D., Gelato M., 1976. Oestrogens and prolactin as possible regulators of puberty. J. Endocr. (in press).

YING S.-Y., GReEP R. O., I97r. Effect of age of rat and dose of a single injection of estradiol benzoate (EB) on ovulation and the facilitation of ovulation by progesterone (P). Endocrinology, 89, 785-79o. 